\title{
Communication between participants and non-participants in analytical capacity building projects: Management advice to family farms in Benin
}

\author{
Marine Rouchouse ${ }^{a}$, Nicolas Faysse ${ }^{b}$, Aurelle De \\ Romemont ${ }^{\mathrm{a}}$, Ismail Moumouni ${ }^{\mathrm{c}}$, Guy Faure ${ }^{\mathrm{a}}$ \\ ${ }^{a}$ CIRAD, Innovation Research Unit, Montpellier 34398, \\ France ; ${ }^{b}$ CIRAD, G-EAU Research Unit, Ecole Nationale \\ d'Agriculture de Meknès, km 10, Haj Kaddour Road, \\ Meknès BP S/40, Morocco; ' ${ }^{\mathrm{F}}$ Faculty of Agronomy, \\ University of Parakou, Parakou BP1269,Benin
}

This is the post-peer reviewed version of the article with the same title, which has been published in the Journal of Agricultural Education and Extension, 21(4), see http://www.tandfonline.com/doi/abs/10.1080/1389224X.2014.928225.

ABSTRACT. Purpose: Approaches to build farmers' analytical capacities are said to trigger wideranging changes. This article reports on the communication process between participants and nonparticipants in one such approach, related to the technical and management skills learned by participants and the changes these participants subsequently made, and the outcomes in terms of non-participants' learning.

Design/methodology/approach: In this study, we analysed the following: i) participants' learning and changes in social practices; ii) communication between participants and non-participants regarding technical and management skills and changes in social practices; iii) non-participants' learning and changes in social practices. The case study was a management advice to family farm project in three villages in Benin.

Findings: Most participants learned management skills, which led them to reassess their objectives and to reduce traditional social practices they now considered unproductive. Even in the case of frequent communication, non-participants found it difficult to learn management skills, which hindered their experiential learning. Non-participants consequently had difficulty understanding why participants changed their social practices such as reduction of their traditional gift giving, leading to limited well-argued discussion about these changes in practices between participants and nonparticipants.

Practical implication: This study shows that, due to the limited learning process of non-participants communicating with participants, there is a need to design and test approaches to achieve capacitybuilding while including more participants at a similar cost, and to stimulate explicit discussion at village level about the changes in values and social practices that these approaches may trigger.

Originality/value: The article analyses both participants and non-participants' experiential learning, and looks at the two sides of the interaction between the communication processes and nonparticipants' learning.

Key words: analytical skills; Benin; capacity building; communication; farmer group; management advice 


\section{Introduction}

Since the 1990s, different approaches have been developed to build farmers' capacities to analyse their situation and take decisions accordingly. These approaches include farmer field schools (FFS) (Braun and Duveskog, 2008), and in West and Central Africa, management advice to family farms (MAFF) (Faure and Kleene, 2004). In the MAFF approach, farmers learn to use management tools based on written records of technical and financial data related to their farming practices and household activities.

These approaches enable participants to undergo a multi-dimensional learning experience and to acquire a broad range of capabilities far beyond farming skills (Van den Berg and Jiggins, 2007). Quantitative studies of FFS reported increased social skills (for example, the ability to speak confidently in public, David, 2007), empowerment (Friis-Hansen and Duveskog, 2012), enlarged social capital (David and Asamoah, 2011), and improved capacities for collective action (Simpson and Owen, 2002; David and Asamoah, 2011). Using a qualitative approach, Duveskog et al. (2011) observed that farmers had more self-confidence and a greater sense of individual agency. Djamen et al. (2010) showed that the MAFF approach reinforced farmers' decision-making capacities.

Even though MAFF and FFS approaches are different in terms of methods and tools to build capacities, developing analytical capacities entails in both cases organising a series of meetings with stable groups of farmers. The cost per farmer is consequently higher than in more classical extension approaches (Bentley et al., 2007), and often only a minority of farmers living in the regions where the projects take place, actually participate. In Asian countries, where FFS programs have been implemented on a large scale, between one and five percent of all the farmers in the countries concerned took part (Van den Berg and Jiggins, 2007). Because of this constraint, there has been a lively debate about the merits of FFS and MAFF compared to other extension approaches (Faure and Kleene, 2004; Bentley, 2009).

Many studies have assessed communication between participants and non-participants and the extent of learning by non-participants, in order to link the cost of such approaches with their impacts. Most of these studies on FFS focused on the communication process and on the management skills learned by non-participants. They showed that communication between participants and non-participants was mainly limited to members of the same household and farmers who were kin (Nathaniels, 2005; Palis et al., 2005; David, 2007). Analyses of non-participants' learning often measured the efficiency of the interactions between participants and nonparticipants, using a model of diffusion of innovations (Rogers, 1995). The analyses produced diverging results (Davis et al., 2012). Feder et al. (2004), Rola et al. (2002), and Erbaugh et al. (2010) found very limited transmission of knowledge to non-participants, whereas Bunyatta et al. (2006) found the opposite. Several authors (Tripp et al., 2005; David, 2007) described the kind of knowledge that was communicated in more detail and showed that 'specific practices and skills or complete technologies (...) are more readily shared than agro-ecological concepts or principles' (Nathaniels, 2005).

There have been far fewer studies on the way the participants' multi-dimensional learning may be communicated to non-participants. The communication process based on such learning raises several questions. A first question is to what extent non-participants, thanks to communicating with participants, have the same multidimensional learning experience as participants. Friis-Hansen et al. (2012) and Najjar et al. (2012) reported increased gender equity in the household due to transformative learning by both participants in FFS and non-participants. Participants' experiential learning may also trigger changes in their relations within the household and in the village in which they live. A second question is thus to what extent non-participants understand the rationale behind the changes in participants' social practices, so as to be able to have a well-argued discussion with participants around these changes. 
The present article analyses the communication between participants and non-participants in villages where an analytical capacity building approach is underway. It assesses the process of communication between participants and non-participants vis-à-vis participants' learning, and the outcomes in terms of non-participants' learning. The subject of the case study was the MAFF Procoton project in three villages in Benin. MAFF is of particular interest for such a study as knowledge learned during the training course applies to agricultural practices, to farm management, and also to management of the household. Therefore the studied communication processes and outcomes were based on participants' learning in terms of technical and management skills, as well as in terms of changes in social practices. The study was part of the evaluation of the impacts of MAFF projects in West and Central Africa. None of the authors of this paper were involved in the Procoton project.

\section{Management Advice to Family Farm - a Case Study in Benin}

Like FFS, the MAFF approach works with the same groups of farmers over a period of time. The groups are often created specifically for the purpose. The trainer and farmers use management tools to jointly analyse the situation of each farm, identify problems and solutions, and schedule future activities. Exchanges between farmers take place during meetings, field visits, and experimental trials. The MAFF educational philosophy differs from that of FFS. FFS starts with observation and experimentation, from which generalisation and conceptualisation emerge (Simpson and Owen, 2002), while MAFF starts with a form of conceptualisation which is achieved by teaching management tools. These tools are subsequently used by participants in their own situations, leading to a new phase of conceptualisation and reflection on their own situation and environment. In addition, the FFS approach generally focuses on agricultural production, whereas the MAFF approach aims to build farmers' capacities to manage both farm and non-farm activities (Faure et al., 2011). MAFF is more recent and has been the subject of far fewer studies than FFS.

The Procoton project was still underway when the present study was conducted. The idea behind the Procoton project was that farmers can improve the technical and economic performance of their farm through improved management of the resources of the farm as a whole (Procoton, 2009). The aim of the Procoton project was thus to increase farm income by helping farmers take appropriate organisational, economic, and technical decisions for the development of their farms. The main Procoton project document (Procoton, 2009) did not mention the question of communication of knowledge to non-participants, nor did it address the issue of the changes in social practices that the project may trigger.

The Procoton project produced four notebooks to enable farmers to keep a written record of their agricultural activities and household accounts. The project aimed to train farmers how to use these notebooks and how to act according to the analyses they would be able to undertake by using them. The accounts notebook was used to keep track of expenses and income for both the farm and the household. The second notebook was for the management of labour (family and paid labourers). The third was for management of the food stock to balance the family consumption needs and the family financial objectives the farmer can achieve by selling crops. The fourth was for planning and monitoring the use of farm inputs, for example, seeds and fertilisers.

In the villages, implementing MAFF was the responsibility of farmer facilitators and supervisors, who were trained by an NGO. Each farmer facilitator managed one group and lived in the same village as his or her group. Each supervisor was in charge of monitoring four or five groups. Three villages in the Didja municipality in south-western Benin were selected for the present study because they hosted active MAFF farmers' groups s. Another MAFF project (called Padse) had previously (1998 to 2005) been implemented in the Djidja region. The Padse project had trained a small number of farmers in the same three villages (Table 1). Most of these farmers became supervisors or facilitators in the Procoton project. The Procoton project was originally designed to improve cotton production. However, a crisis in the cotton sector after the agreement between the donor and local partners had 
been signed led to a major reduction in cotton production. The donor decided to go forward with the project, but in Djidja municipality, it no longer focused on cotton production.

Weekly meetings of farmers groups were organised. Every second meeting focused on reading and writing in Fongbe, the local language, as French is the language of instruction in schools in Benin. The other meetings focused on how to fill in the notebooks using Fongbe language, and how to plan decisions based on their analysis. Farmer facilitators and supervisors used these regular training courses to teach the farming techniques they had themselves learned during the Padse project. These techniques were generally aimed at more intensive farming (for example, increased and better use of chemical fertilisers) in a context where farmers rarely use external inputs. The facilitators also organised individual follow-up sessions to check how the participants were filling in their notebooks. Facilitators used the data recorded in the notebooks to support farmers in their decision making. The Procoton method involves less interaction between farmers and advisors and less time is dedicated to providing individual advice, than other MAFF projects (Faure et al., 2004).

Table 1 Number of participants and non-participants in the three villages

\begin{tabular}{lcccc}
\hline & Gboguedekpa & Kpatakpodji & Wokpa & Total \\
\hline Number of households & 32 & 45 & 20 & 97 \\
No. of participants in the Padse project (1998-2005) & 8 & 4 & 2 & 14 \\
No. of participants in the Procoton project (after Dec 2009) & 43 & 24 & 2 & 69 \\
Female participants & 25 & 2 & 0 & 27 \\
Male participants & 18 & 22 & 2 & 42 \\
No. of participants interviewed & 19 & 15 & 1 & 35 \\
No. of non-participants interviewed & 13 & 35 & 6 & 54 \\
\hline
\end{tabular}

Some features of the study region are important to understand the way MAFF can influence farmers' activities and social relationships in the households and in the village as a whole. Almost all the inhabitants of the villages where the study took place belonged to the Fon ethnic group. Fon traditions place great importance on social relationships. For example, ample food and drink are provided to guests, and gifts for weddings or funerals are highly valued. Religions have also a strong influence on norms and values. Several religions, including Christianity and Islam, are practised in Benin. However, Vodun, the traditional religion, still plays a major role. Vodun ceremonies often require participants to spend a lot of money (Mayrargue, 2002). In the Fon tradition, men have to financially support their family and give their wives money for several items of expenditure, including food (Falen, 2009). Men make the agricultural decisions concerning their fields while their wives and children carry out specific tasks in their husband's/father's field, including sowing, hoeing and spreading fertiliser. The wife often has a small field of her own to cultivate and generally uses the money she earns to purchase personal items. The husband's and wife's accounts are thus linked, but nevertheless separate. Men and women who took part in the Procoton project recorded their individual accounts in the accounts notebook.

\section{Research Methodology}

\section{Analytical Framework}

The study of the process and outcomes of communication between participants and non-participants needs to be based on a model of learning that will be used for both participants (as a basis to understand what they may communicate) and non-participants. The model used in the present study was based on experiential learning theory, which defines the learning process as resulting from a cyclic interaction between active experimentation, concrete experience, reflective observation, and abstract conceptualisation (Kolb, 1984). The learning process analysed here was conceptualised in a 
similar way and was assessed as the interaction between i) the learning and use of skills; ii) changes in household management and social practices; iii) the farmers' own assessment of the impacts of these changes at household and village levels; and iv) changes in the farmers' frame of reference and objectives (see Figure 1). A frame of reference is defined here as the 'structure of assumptions and expectations on which our thoughts, feelings and habits are based' (Mezirow, 2009). The household corresponds to the family unit, defined here as the group of people related to the family head; that is, a man married to one or several women with their dependent children.

The study focused on the knowledge taught during MAFF activities which led farmers to change their practices. Farmers may have acquired new knowledge without putting it into practice, for instance because they did not have the resources or the desire to do so. Since such knowledge was not put to use, it is not included in Figure 1. As a result, the study only assessed farmers' learning of skills, broadly defined as 'outward manifestations showing that someone knows how to do something' (Vreyens and Shaker, 2005). MAFF activities included learning technical skills so that farmers could improve the way they cultivate their fields. It also taught management skills, which required literacy, since they involved the use of notebooks. The skills taught (in written form) were the management of family accounts (first notebook), labour force (second notebook), harvest (third notebook), and inputs (fourth notebook). Management included the planning, monitoring and evaluation of actions, and reflection upon this process. Changes in household management concerned changes in spending and in saving practices, in particular participation in tontines (merry-go-round savings). Farmers also learned how to plan household expenditure more efficiently, which may not necessarily require using written information. In this study, we did not assume that the skills learned by participants and the changes they made were inherently positive.

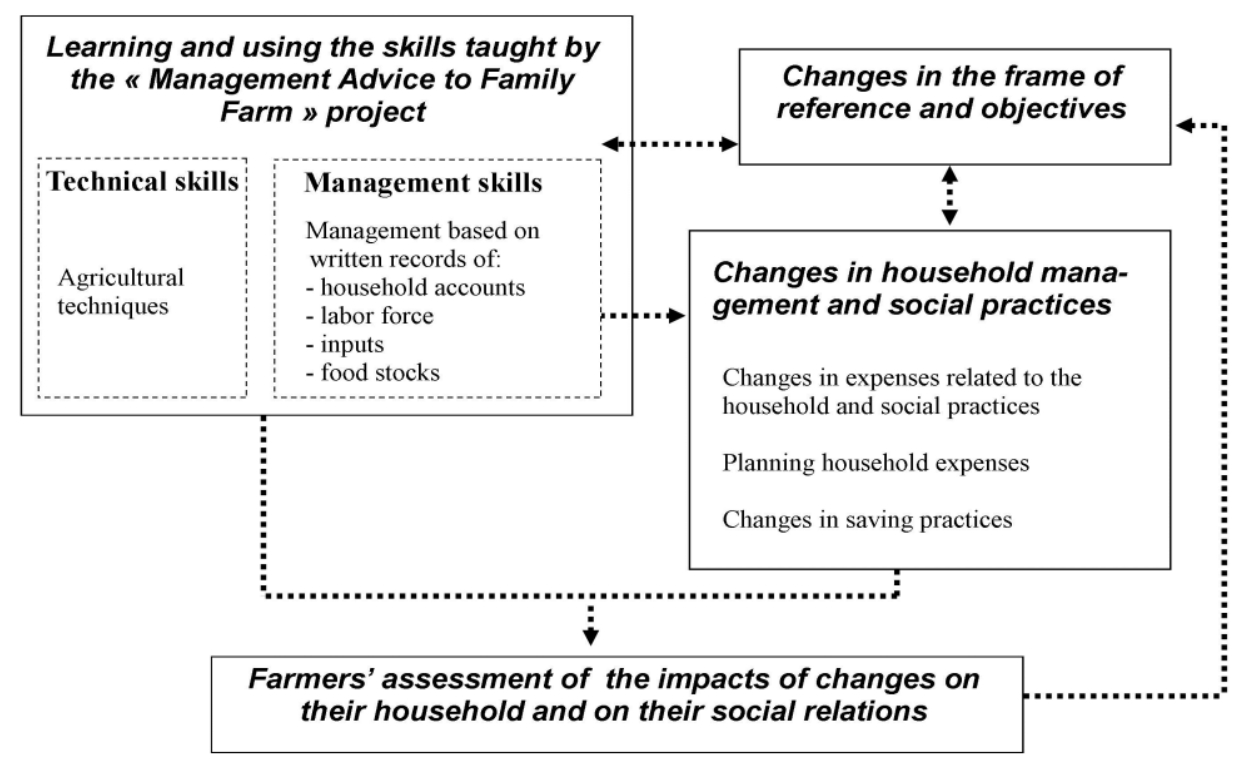

Figure 1. The learning process cycle

\section{Data Collection and Analysis}

Field work was conducted from November 2011 to February 2012 in the villages of Gboguedekpa, Kpatakpodji and Wokpa. The Procoton project had created two groups in Gboguedekpa, one group of 25 women and one group of 21 men (see Table 1). Two participants in the men's group in 
Gboguedekpa lived in Wokpa, where there was no MAFF group. In Kpatakpodji, the Procoton project created a group of 24 participants, which included two women.

Most data were collected during semi-structured interviews with farmers. The study was presented to interviewees as a research project, which was not linked to Procoton. First, 30 MAFF participants were interviewed along with five farmers who were also Procoton supervisors or facilitators (and who were included in the group of participants for the analysis of the skills learned by this group and the changes in practices made by members of this group). The participants who were interviewed generally represented one third of each MAFF group (Table 1). Participants for interview were selected to cover a range of situations in terms of gender, age, and prior participation in the Padse project. Second, 54 non-participants were selected for interview using a snowball sampling technique. Their names were provided by participants as people with whom they discussed the skills and practices taught during Procoton meetings. Farmer facilitators and supervisors also identified farmers who had either no link with participants or who had a negative opinion of the Procoton project. Thirteen of the participants interviewed were women, and 21 of the non-participants interviewed were women. Each interview was individual. Interviews were conducted with the help of a Fon/French interpreter.

During the interview, the participants and non-participants were first asked what they produced on their farm and about their technical practices. They were then asked if they had recently learned anything about the household and farm management skills shown in Figure 1, and whether they had recently changed their household and farm management practices. If changes had been made, farmers were invited to tell us the origin of the changes (in other words, we did not openly suggest that MAFF or communication with MAFF participants was the reason for the change). To assess possible knowledge which was not put into practice, questions were asked concerning maize, the main crop grown in the three villages in which the study was conducted. They were asked whether they were familiar with the maize cropping techniques recommended by Procoton staff, irrespective of whether they actually implemented these techniques. Second, both participants and nonparticipants were asked if they discussed about MAFF and MAFF topics, and if yes, how often, what exactly they discussed, and the type of social relationship they had with the people they talked to. Non-participants were asked whether they had learned any skills from Procoton participants. Third, non-participants were invited to identify the changes in agricultural production, household management and social practices triggered by communication with MAFF participants. Concerning their social practices, they were also asked if they had recently changed any Vodun religious practices. Fourth, they were asked about any plans they had for the future. Finally, both participants and non-participants were asked to what extent they thought MAFF activities had changed participants' social practices.

Complementary interviews were conducted to obtain other points of view on the implementation and impacts of MAFF. These interviews were conducted with two farmers who had originally joined, but subsequently left MAFF groups and did not complete the training. Interviews were also conducted with 12 community and religious leaders, and with four non-farmer staff of the Procoton project. At the end of the data collection period, workshops were held in each village to present and discuss preliminary results.

Most of the data we used were the interviewees' own assessment of their learning and changing practices. We confirmed what the interviewees told us about their learning first by asking them to give us a detailed description of the skills they thought they had recently learned. Second, many interviewees showed us their notebooks on their own initiative. Third, in some cases, field visits enabled us to see farmers' practices for ourselves.

We first analysed participants' learning of technical and management skills and changes in social practices. Second, we analysed the reasons why non-participants did not join MAFF and the strategies of participants and non-participants to enable non-participants to learn the same skills as the participants. Third, we assessed non-participants' learning and changes in social practices. We analysed to what extent the frequency of communication between participants and non-participants 
influenced non-participants' learning. Finally, we assessed whether the differences in learning between participants and non-participants affected farmers' capacities to collectively discuss the changes in social practices implemented by participants.

\section{Results}

\section{Participants' Learning}

All the participants mentioned that their recent learning and changes in practices were linked with MAFF. Table 2 lists the skills participants told us they most often taught to non-participants and displays the number of participants who learned each skill.

All the participants learned some of the agricultural practices recommended by Procoton staff. Supervisors and farmer facilitators gave different advice but all with the same goal of intensification (that is, to cultivate less land more efficiently). Such a choice to promote intensification was debated during MAFF meetings by comparing the increase of production costs involved with the farming practices promoted by Procoton, and the increase of yield these practices permitted. In practice, participants mainly learned the maize and soy cropping calendars, which are the main crops cultivated in the three villages. All the participants learned the maize cropping techniques taught by the MAFF facilitators. However, six of the 35 participants did not apply the recommended techniques, because of the price of fertilisers and the increased effort these techniques required.

The most frequently learned management skills were related to the use of management notebooks, to plan the purchase and storage of fertilisers or grains depending on market prices. Participants who learned to plan the purchase and use of fertilisers stressed that the correct use of fertilisers was crucial for the success of the new farming practices recommended by Procoton. Participants who learned to store and sell their harvest depending on market prices no longer rushed to sell their crops immediately after harvest or when they needed money. Instead, they waited until market prices were high enough to cover their production costs. The skill required to monitor the work performed by labourers and food consumption was much less frequently learned. However, one participant explained that, as a result of MAFF training, he had noticed that when he hired villagers in the morning, they did not work much in the morning plus he was obliged to give them lunch. Consequently, he preferred to hire labourers only in the afternoon. Such an example shows that MAFF impacts could be seen as positive or negative depending on the point of view.

By filling in monthly and yearly balance sheets in their accounts notebook, participants realised which items of expenditure financially 'ruined' them, as many interviewees put it. The main changes they made as a result were the following: i) they kept more detailed household accounts; ii) they reduced some of their household expenses; and iii) they increased other expenses, made investments, or saved their money. Table 2 lists the changes in household management and in social practices most frequently cited by participants as being due to the MAFF.

Four fifths of the participants reduced household purchases and started to buy only what they considered to be essential. They went less frequently to local markets with friends so they would be less tempted to buy things they did not need. The women told us that they had learned to plan the purchase of goods including condiments, soap, oil, charcoal, and matches, and now paid more attention to how they used these items than before. Participants also changed social practices that entailed expenses. Two thirds of the participants drastically reduced what they spent on food and drinks for guests, with the exception of guests who were very close to the family. Twenty-five of the 35 participants also reduced the money they contributed to funerals. Finally, one quarter of the participants said that after analysing their accounts, they realised how much Vodun ceremonies cost and had considerably reduced the amount they contributed.

Participants reinvested the money they saved in their farm or in improving the well-being of their family. Six of the 13 women spent the money they earned from their own field differently. They had decided to reduce personal expenses and to increase certain household expenses their husband had 
previously paid for, such as food or medical care. Women were keen to pay because they considered their husbands did not fulfil their responsibilities and they realised that improving their family's wellbeing was not only possible but rewarding. Half the participants had joined tontines to prepare for future investments.

Table 2 Skills learnt by participants and non-participants and changes in practices

\begin{tabular}{|c|c|c|c|}
\hline Skills and practices & $\begin{array}{l}\text { Participants } \\
\text { (35 interviewed) }\end{array}$ & $\begin{array}{l}\text { Non-participants } \\
\text { who communicated } \\
\text { with participants } \\
\text { (40 interviewed) }\end{array}$ & $\begin{array}{l}\text { Non-participants } \\
\text { who did not } \\
\text { communicate with } \\
\text { participants (14 } \\
\text { interviewed) }\end{array}$ \\
\hline \multicolumn{4}{|l|}{ Technical skills } \\
\hline Use of maize cropping techniques advised by Procoton & 29 & 32 & 4 \\
\hline \multicolumn{4}{|l|}{ Management skills } \\
\hline Use of management notebooks & 31 & 0 & 0 \\
\hline Management of family accounts & 19 & 0 & 0 \\
\hline Hiring of labour based on the Procoton cropping calendar & 12 & 4 & 0 \\
\hline Monitoring labourers' work and food consumption & 8 & 6 & 1 \\
\hline Planning the purchase and storage of fertilisers & 24 & 6 & 0 \\
\hline Storing or selling harvest depending on market prices & 23 & 6 & 0 \\
\hline Written calculations to estimate gross margins & 16 & 0 & 0 \\
\hline Learning of at least one of the above-mentioned skills & 31 & 12 & 1 \\
\hline \multicolumn{4}{|l|}{ Changes in household management and social practices } \\
\hline Purchases limited to indispensable items & 28 & 6 & 0 \\
\hline Joining tontines & 18 & 10 & 0 \\
\hline Planning the use of condiments and soap & 7 & 8 & 0 \\
\hline Reducing the amount of food and drink provided to guests & 22 & 6 & 0 \\
\hline Reducing donations to funerals & 25 & 9 & 0 \\
\hline Reducing donations to Vodun ceremonies & 9 & 8 & 0 \\
\hline Implementation of at least one the above-mentioned changes & s 34 & 20 & 0 \\
\hline
\end{tabular}

Half the participants told us that, thanks to MAFF training, they had succeeded in shortening the lean season. Two of the 13 participant women said that their husband now let them carry more weight in the family decision making. Four women said that attending MAFF meetings had taught them how to express themselves and to speak in public. The traditional head of the community at Gboguedekpa explained that before Procoton, only men met to make joint decisions, but now women were also invited. He remarked that their opinions were taken into consideration like the men's.

Changes in skills and practices, and their impacts on the well-being of the household, triggered a shift in participants' frames of reference and objectives. Participants gave more importance to the economic dimension of farming and now considered farming more as a business. Participants also placed more importance on the well-being of their family, especially with respect to food security. All the participants reported having concrete goals for future investments, for example building a new house, increasing agricultural production, or buying a motorbike.

Twenty-two of the 35 participants said that MAFF reinforced their ability to plan and actually make investments they had previously not been able to make. These participants had moved from a situation in which they 'dreamed about doing things', to a situation in which their dreams could be transformed into concrete goals. They now believed that these goals could be achieved thanks to realistic action plans. All these participants used their accounts notebook and had changed the way they managed their household expenses. They all said they had made at least one change in the three following social practices: receiving guests, donating money for funerals, and going to the 
market with friends. These 22 participants had been through the complete experiential learning loop illustrated in Figure 1.

Reasons for Non-Participation and Communication Schemes between Participants and NonParticipants

Each non-participant gave one or more reasons for not having joined MAFF groups when they first started. Fifteen of the 54 non-participants mentioned lack of time and 15 believed that they did not have the necessary ability to join the MAFF group. In particular, older farmers thought they were too old to learn how to read and write. The distance between where the training course was held and the farmer's home was given as the reason by seven non-participants. Fifteen non-participants said they already had difficulty supporting their family (for example, they lacked food or cash, or had health problems), and they did not want to change the way they farmed in case their situation worsened as a result. Six were simply not interested, and four were waiting to see if MAFF produced positive results in the long term before joining. Three said they did not participate because they disagreed with the social changes which MAFF had triggered at village level.

The positive results of the participants' new farming and household practices, such as increased yields or better control of expenses, was an important element in non-participants' potential desire to learn Procoton skills. As a result, 42 out of the 54 non-participants (that is, almost all the nonparticipants who did not say they disagreed with or were not interested in MAFF) tried to learn the skills and practices taught by Procoton by communicating with participants or by observing what they did. The participants themselves had different reasons for helping non-participants acquire MAFF knowledge. Participants were often keen to teach their non-participating spouses to apply the household management principles taught by MAFF. Another reason was that participants wanted to help improve the villagers' living conditions, especially those of members of their family and of their close friends.

Three different strategies were used by both participants and non-participants to enable nonparticipants to learn the skills and practices taught by MAFF. First, participants tried to persuade nonparticipants to join existing MAFF groups. However, only six of the 69 participants in all the MAFF groups in this study joined a group after it had begun. Indeed, a year after the beginning of the project, the NGO in charge of Procoton decided to stop accepting newcomers because they disturbed the functioning of existing groups. Second, 20 of the 35 participants told us they passed on knowledge related to MAFF to non-participants regularly (that is, through repeated discussions with non-participants on the same topic), and 25 said they did so occasionally. Non-participants who told us they often talked about MAFF always referred to participants as their interlocutor. However, four of the 54 non-participants complained that participants did not make enough effort to share their knowledge. Third, when non-participants were unable to write down data on their farming practices in the notebooks, participants just explained the farming practices, household expenses and savings. One third of non-participants were coached by participants, in the sense that the participant monitored what the non-participant was doing and gave advice.

When not in direct contact with a participant, non-participants used two main strategies to discover the farming practices recommended by Procoton. First, they watched the new practices when they worked as labourers in participants' fields. Second, four of the eight non-participants who were illiterate and who were parents of a young participant had asked their son or daughter to join a MAFF farmers' group with the specific aim of acquiring MAFF knowledge. They then let their son or daughter manage part of the farm to try out the new farming practices, for example, reducing the size of a plot to intensify production.

We classified non-participants in two groups based on their exchanges with participants, as assessed by the non-participants themselves. The first group (40 of the 54 non-participants) comprised nonparticipants who communicated with participants about MAFF. These exchanges were either occasional or frequent, in which case the discussion about MAFF continued from one encounter to the next. Twenty-nine of these non-participants had a participant in his or her family unit. The 
second group (14 of the 54 non-participants) included non-participants who, with rare exceptions, did not discuss the knowledge taught by MAFF with participants. Only two of these non-participants had a participant in their family unit.

\section{Non-Participants' Learning}

For each management skill learned by participants, Table 2 shows the number of non-participants who said they had learned this skill. The technical skills taught by MAFF were the most easily transmitted. Only 12 of the 40 non-participants who discussed with participants learned a minimum of one management skill taught during MAFF meetings. Only one of the non-participants who did not discuss with participants learned one management skill taught by Procoton.

Even for the non-participants who communicated with the participants, learning management skills requiring writing was difficult. The cropping calendar recommended by Procoton required a written record of the date of each operation to better plan the activities or to monitor them. However, most non-participants were not able to use the notebooks to monitor their farming practices because of their limited literacy level (the great majority of non-participants did not have a basic literacy level) and because they did not receive enough help to be able to fill in the notebooks. These nonparticipants thus understood the principles behind the use of management skills, and were aware of the qualitative changes that needed to be made. However, they could not make the necessary calculations for a reflexive analysis of their current practices and of changes that could be made on their farm. None of the non-participants learned how to manage the household budget and make written calculation to estimate gross margins.

Among the 40 non-participants who discussed MAFF with participants, 22 told us they had received advice on how to change the way they spent and saved household money. Twenty of these 40 nonparticipants implemented at least one of the changes in household management and social practices made by participants (Table 2). Nine of the 21 female non-participants learned how to plan the use of household goods. Eight of the 10 female non-participants married to a participant improved their household management thanks to discussions with their husband. Four participating children of nonparticipating parents had acquired more weight in family decision making, as their parents let them experiment and were willing to learn from them. However, cultural norms limited the extent to which young participants could transmit what they had learned to the older generation, and the other four non-participating parents of participating children did not change their practices. Nonparticipants who did not communicate with participants did not change their household management and social practices.

Three of the 21 female non-participants married to participants managed to save more money from the sale of their crops. Eleven of the 54 non-participants (irrespective of whether they communicated with participants or not) said that they had succeeded in shortening the lean season, mainly thanks to their new technical skills. Finally, none of the non-participants had changed their way of setting goals for their household based on the attitude to management promoted by MAFF. In other words, they did not go through the same complete experiential learning loop as the participants.

\section{Uneasy Communication on Diverging Social Practices}

The changes in social practices made by participants were criticised by non-participants (however, a limited number of non-participants implemented some of these changes, as shown in Table 2). For instance, before Procoton, villagers used to work in fields belonging to friends or to their extended family because they knew that they would receive large quantities of food during the working day. A non-participant complained that, once MAFF started, he received much less food and what he got was barely enough to justify working in participants' fields. In their responses concerning the role of MAFF in changing participants' social practices, 16 of the 35 participants told us that they were now called 'stingy' by non-participants. Non-participants explained that they gave participants this nickname as a way of expressing their disapproval of the changes in the participants' social behaviour. Participants said they did not worry about the nickname because they saw the advantages of MAFF. 
This marked difference in viewpoints between participants and non-participants was also due to their diverging understanding of the changes undertaken by participants in their social practices. Participants said that they were right to question social practices since they now realised these practices were not necessary and 'ruined' them financially, especially since participants now gave more priority to the well-being of their family. Non-participants did not understand the logic behind these changes and believed the changes threatened the foundation of social relations in the community. When judging MAFF, non-participants found it difficult to distinguish between learning analytical capacities -which they approved- from changes in social practices, of which they often disapproved. A former MAFF participant explained that he had dropped out because donations for mutual support and traditional ceremonies were not taken into account by Procoton. This misunderstanding contributed to the non-participants' impression that changes were happening too fast and too aggressively.

During the workshop held in Kpatakpodji to present preliminary results, non-participants and participants had a discussion about funeral expenses. Both groups told us that the workshop was the first time they had ever talked about what would be the right amount of money to give in a calm and reasoned discussion. They said that this discussion had helped them understand each other's point of view.

Procoton staff did not discuss these changes in social practices with their groups of participants or with the village as a whole. The position of the Procoton staff concerning the changes in social practices was complicated. On the one hand, the NGO in charge of project implementation considered that the project was focused on improving farmers' capacities to make decisions with the aim of increasing their income, and that giving advice on any particular expense, social practice, or on which religion to follow, was not part of their mandate. Similarly, the supervisors and farmer facilitators insisted that they never told farmers what they should do about donations and other social practices during regular MAFF meetings. They said they let the participants choose which expenses they wanted to reduce based on the analysis of their monthly and yearly balance sheets. On the other hand, during individual coaching sessions, local staff sometimes took the opportunity to give advice on a case by case basis. In this case, they often advised villagers to steer clear of social practices that involved high expenses.

\section{Discussion}

\section{Management Skills: A Major Stumbling Block to Non-Participants' Experiential Learning}

The learning of management skills played a key role in participants' experiential learning. The notebooks were intended to be used as a discussion support between Procoton facilitators and farmers, with the aim of building farmers' capacities to judge their own situation and plan their future actions. In practice, Procoton facilitators' interactions with participants around the notebooks mainly focused on how to fill them in. However, despite the facilitators' limited use of the notebooks as a support for giving advice at meetings or during field visits, the participants' own use of the notebooks facilitated the experiential learning process. Learning management tools enabled them to reassess their own situation, environment and objectives, to better assess their room for manoeuvre and to undertake major changes in the management of their farm and household. As in the case of FFS (Taylor et al., 2012) instrumental learning (learning focused on improving the ability to manage the environment, in particular in terms of farming techniques) played a key role in enabling transformative learning.

Concerning non-participants' learning, as reported in a study on FFS (Tripp et al., 2005), communication between participants and non-participants enabled non-participants to learn technical skills but few management skills. It was very difficult for participants to pass on new management skills to non-participants. Consequently, even when non-participants were interested in managing their farm and their household in the same way as participants, they were unable to make informed decisions about the new farm and household practices because they did no't experience a 
similar learning process. As a result, none of the non-participants who tried to make the same changes as participants completely succeeded.

Learning management skills was thus a major obstacle for non-participants and prevented them from completing the experiential learning loop like the majority of participants. However, this does not mean that non-participants were not influenced by the changes made by participants. Nonparticipants' frames of reference were challenged, as they witnessed and acknowledged the success participants achieved as the result of changing their practices. Moreover, non-participating husbands of participating women often gave their wives a bigger role in household decision making. This outcome was also reported in FFS (Friis-Hansen and Duveskog, 2012). These significant differences between participants and non-participants in terms of learning management skills and experiential learning raises an equity issue (as pointed out by Feder et al., 2010 in the case of FFS).

In the MAFF project that was the subject of the present study, the use of written documents was one of the main reasons why some farmers did not take part, as they could not or did not want to learn to read and write in order to participate. Other MAFF experiments (for instance, AFDI, 2012) addressed this issue by creating different groups in the same village. In one of the groups, farmers learned management concepts but do not have to fill in notebooks.

\section{A Lack of Discussion of the Changes in Values Underlying Social Practices}

Participants and non-participants discussed management skills, but did not discuss participants' evolving social practices and even less the changes in the values that supported such practices. The values on which participants based their social practices evolved considerably. In Benin, social norms in the village determine how goods and money circulate between households with different levels of wealth. This takes place openly, one example being money donated for funerals. But it also takes place less openly, for example, the way food is supplied to farm workers in addition to their wages. Participants started questioning these practices, arguing that tradition was no longer a justification for continuing these social practices. Half the participants decided to start tontines, in which social links are based on a fundamentally different system, with a different goal (working together to facilitate saving) and a different definition of the group (tontines include only farmers who are in a position to save money). These changes in values linked to introducing 'Western-style' management have already been identified in the literature. In particular, Gordon (1996) argued that Western-style management weakens kinship bonds, which were formerly considered to be more important than differences in wealth, and shifts the importance previously given to the community to one more focused on the nuclear family.

The lack of discussion between participants and non-participants of these changing values was first due to the fact that many of these changes were not easily made explicit. The use of MAFF notebooks helped create a representation of the household that focused on its economic dimension (Moumouni et al., 2011), and this bias was not discussed in the MAFF groups that were the subject of the present study. Second, non-participants considered participants' changes in values as part of the same general trajectory of change, which included both better management of accounts and changes in social practices. Non-participants could not understand how these changes were linked, and were consequently unable to imagine that improved analytical skills may be associated with changes in social practices other than those undertaken by participants. There was thus very limited discussion at village level about what can be considered relevant or irrelevant values and related social practices, and which of these values and social practices should be maintained or, on the contrary, should evolve.

\section{Conclusion}

The MAFF project studied here resulted in significant changes in participants' management skills. It enabled 22 of the 35 participants to go through a complete experiential learning cycle. These quantitative results with regards to participants' learning are not representative of the MAFF project as a whole, since the villages chosen for this study were selected because of the dynamism of their 
farmers' groups. The communication schemes between participants and non-participants in the MAFF project were similar to those described in FFS case studies: most participants attempted to pass on the knowledge they had acquired during the training course, preferentially to members of their own household.

The sampling method chosen meant that no statistical assessment could be made about the respective share of non-participants who communicated and those who did not communicate with participants in the villages concerned. What is significant (taking into account the limited size of the sample) is that: i) among the 14 non-participants who did not communicate with participants, only one learned a management skill and none made any changes in household management or social practices; ii) half the non-participants who communicated with participants changed their household management and social practices, but less than a quarter learned one or more management skills. Making changes in household management and social practices, which did not require literacy, was not as difficult as learning management skills. Communication with participants appeared to be a necessary pre-condition for most non-participants to learn management skills, but was not a sufficient one for them to learn these skills, to develop reflexive analysis, or to change their household management and social practices.

The limited number of non-participants who learned management skills confirms the results of several studies on FFS. The present study had three main innovative results. First, both participants and non-participants developed different strategies to communicate about the skills taught by MAFF. In particular, non-participants who had difficulty learning management skills had their son or daughter join a MAFF group, or received frequent advice from participants on the management of their farming activities. Second, non-participants who learned management skills from participants did not fully master these skills and did not undergo the same experiential learning process. Third, non-participants rarely discussed participants' changing social practices with participants. This was not due to lack of opportunities for communication, as many participants and non-participants discussed management skills. It was rather because non-participants actually learned only a few management skills, leading to a very limited experiential learning process related to MAFF. All of which contributed to an increasing 'cognitive gap' between participants and non-participants.

This study shows that approaches like FFS and MAFF, which aim to build analytical capacities, should take more into account that the dissemination of new knowledge related to management skills is not something happening easily. First, ways could be found to increase the number of participants without increasing the cost of the training. This could mean shorter and less detailed training, and, in the case of MAFF, possibly less use of notebooks. Less complex learning by participants would also be easier to communicate to non-participants. However, further research is required to understand whether using 'lighter' methods would enable the same kind of experiential learning as longer and more complex curricula. Second, there is need to address constraints in non-participants' learning and support improved communication between participants and non-participants. Third, approaches aimed at building analytical capacities must also help non-participants understand the changes in values and social practices made by participants as a result of their improved analytical capacities and not only focus efforts on intending to disseminate management skills. Such approaches could play an active role in supporting a much more informed discussion between participants and nonparticipants about the social practices in their communities and about the values on which these practices are based. The appropriate adaptation of these approaches would help create advisory services which do not focus only on the household but pay more attention to village dynamics.

\section{References}

AFDI (2012) Guide pratique. Quel Accompagnement Proposer à une Organisation Paysanne pour Choisir une Activité de Conseil à l'Exploitation Familiale (CEF) ? http://www.afdiopa.org/fr/images/ uploaded/admin0509/Dossiers\%20et\%20analyses/guide\%20CEF.pdf (Downloaded January 2013).

Bentley, J.W. (2009) Impact of IPM Extension for Smallholder Farmers in the Tropics, in: Peshin R. and Dhawan, A.K. (Eds) Integrated Pest Management. Dissemination and Impact 2. New York: Springer, pp. 333-346. 
Bentley, J.W., Barea, O., Priou, S., Equise, H. \& Thiele, G. (2007) Comparing Farmer Field Schools, Community Workshops, and Radio: Teaching Bolivian Farmers about Bacterial Wilt of Potato. Journal of International Agricultural and Extension Education, 14(3), pp. 45-61.

Braun, A. \& Duveskog, D. (2008). The Farmer Field School Approach - History, Global Assessment and Success Stories. Background Paper for the IFAD Rural Poverty Report 2011.

Bunyatta, D.K., Mureithi, J.G., Onyango, C.A. \& Ngesa, F.U. (2006) Farmer Field School Effectiveness for Soil and Crop Management Technologies in Kenya. Journal of International Agricultural and Extension Education, 13(3), pp. 47-63.

Davis, K.E., Nkonya, E., Kato, E., Mekonnen, D.A., Odendo, M. \& Miiro, R. (2012) Impact of Farmer Field Schools on Agricultural Productivity and Poverty in East Africa. World Development, 40(2), pp. 402-413.

David, S. (2007) Learning to Think for Ourselves: Knowledge Improvement and Social Benefits among Farmer Field School Participants in Cameroon. Journal of International Agricultural and Extension Education, 14(2), pp. 35-49.

David, S. \& Asamoah, C. (2011) The Impact of Farmer Field Schools on Human and Social Capital: A Case Study from Ghana. Journal of Agricultural Education and Extension, 17(3), pp. 239-252.

Djamen, P., Havard, M., Wey, J., Lefèvre, M. \& Djomo, S. (2010) Le Conseil Agricole, une Démarche Porteuse à l'Epreuve des Réalités : Premières Leçons d'une Expérience de Changement d'Echelle au Nord Cameroun. In Proceedings of the ISDA Conference. Montpellier, France, June, 28-30, 2010.

Duveskog, D., Friis Hansen, E. \& Taylor, E.W. (2011) Farmer Field Schools in Rural Kenya: A Transformative Learning Experience. Journal of Development Studies, 47(10), pp. 1529-1544.

Erbaugh, J.M., Donnermeyer, J., Amujal, M. \& Kidoido, M. (2010) Assessing the Impact of Farmer Field School Participation on IPM Adoption in Uganda. Journal of International Agricultural and Extension Education, 17(3), pp. 5-17.

Falen, D.J. (2009) Power and Paradox. Authority, Insecurity and Creativity in Fon Gender Relations. Trenton, New Jersey, USA: Africa World Press.

Faure, G. \& Kleene, P. (2004) Lessons from new experiences in extension in West Africa: Management advice for family farms and farmers' governance. Journal of Agricultural Education and Extension, 10(1), pp. 3749.

Faure, G., Rebuffel, P. \& D. Violas, D. (2011) Systemic Evaluation of Advisory Services to Family Farms in West Africa. Journal of Agricultural Education and Extension, 17(4), pp. 325-339.

Feder, G., Murgai, R. \& Quizon, J.B. (2004) The Acquisition and Diffusion of Knowledge: The Case of Pest Management Training in Farmer Field Schools, Indonesia. Journal of Agricultural Economics, 55(2), pp. 221-243.

Feder, G., Anderson, J.R., Birner, R., \& Deininger, K. (2010) Promises and Realities of Community-Based Agricultural Extension. IFPRI Discussion paper No. 959. Washington DC: IFPRI.

Friis-Hansen, E. \& Duveskog, D. (2012) The Empowerment Route to Well-Being: An analysis of Farmer Field Schools in East Africa. World Development, 40(2), pp. 414-427.

Friis-Hansen, E., Duveskog, D. \& Taylor, E.W. (2012) Less Noise in the Household: The Impact of Farmer Field Schools on Gender Relations. Journal of Research in Peace, Gender and Development, 2(2), pp. 44-55.

Gordon, A.A. (1996) Transforming Capitalism and Patriarchy: Gender and Development in Africa. Oxford: Lynne Reimer.

Kolb, D. (1984) Experiential Learning: Experience as the Source of Learning and Development. Upper Saddle River, New Jersey: Prentice-Hall.

Mayrargue, C. (2002) Dynamiques Religieuses et Démocratisation au Bénin. Pentecôtisme et Formation d'un Espace Public. PhD in Political Sciences, University of Bordeaux IV, France.

Mezirow, J. (2009) Transformative learning theory. In: J. Mezirow \& E.W. Taylor (Eds) Transformative Learning in Practice: Insights from Community, Workplace, and Higher Education. San Francisco: Jossey-Bass.

Moumouni, I., Nouatin, G.S. \& Baco, M.N. (2011) Du Système Formation et Visites au Conseil à I'Exploitation Agricole Familiale au Bénin: Rupture ou Continuité? Cahiers Agricultures, 20(5), pp. 376-381.

Najjar, D., Spaling, H. \& Sinclair, A.J. (2012) Learning about Sustainability and Gender through Farmer Field Schools in the Taita Hills, Kenya. International Journal of Educational Development, http://dx.doi.org/10.1016/j.ijedudev.2012.06.004.

Nathaniels, N.Q.R. (2005) Cowpea, Farmer Field Schools and Farmer to Farmer Extension: A Benin Case Study. Agricultural Research and Extension Network Paper No. 148. London, UK: ODI.

Palis, F.G., Morin, F. \& Hossain, M. (2005) Social Capital and Geography of Learning: Roles in Accelerating the Spread of Integrated Pest Management. Journal of Agricultural Education and Extension, 11(1-4), pp. 2737.

Procoton (2009) Stratégie de Mise en CEuvre du Conseil aux Exploitations Familiales (CEF) Piloté par les Organisations Paysannes. SNV and Association Nationale des Producteurs de Coton du Bénin.

Rogers, E.M. (1995) Diffusion of Innovations. New York: Free Press. 
Rola, A.C., Jamias, S.B. \& Quizon, J.B. (2002) Do Farmer Field School Graduates Retain What They Learn? An Investigation in Iloilo, Philippines. Journal of International Agricultural and Extension Education, 9(1), pp. 65- 76.

Simpson, B.M. \& Owen, M. (2002) Farmer Field Schools and the Future of Agricultural Extension in Africa. Journal of International Agricultural and Extension Education, 9(2), pp. 29-36.

Taylor, E.W., Duveskog, D. \& Friis-Hansen, E. (2012) Fostering Transformative Learning in Nonformal Settings: Farmer Field Schools in East Africa. International Journal of Lifelong Education, 31(6), pp. 725-742.

Tripp, R., Wijeratne, M. \& Piyadasa, V.H. (2005) What Should We Expect from Farmer Field Schools? A Sri Lanka Case Study. World Development, 33(10), pp. 1705-1720.

Van den Berg, H. \& Jiggins, J. (2007) Investing in Farmers - the Impacts of Farmer Field Schools in Relation to Integrated Pest Management. World Development, 35(4), pp. 663-686.

Vreyens, J.R. \& Shaker, M.H. (2005) Preparing Market-Ready Graduates: Adapting Curriculum to Meet the Agriculture Employment Market in Egypt. In Proceedings of the 21st Annual Conference of the Association for International Agricultural and Extension Education. San Antonio, Texas, May, 25-31. 